\title{
GENETIC DIVERSITY OF EIGEYE TUNA (Thunnus obesus) BASED ON mLDNA ANALYSIS WITH THE PCR-RFLP TECHNIQUE
}

\author{
Budi Nugraha'1, Mulyono Sumitro Baskoro'1), Anwar Bey Pane ${ }^{21}$, and Estu Nugroho ${ }^{31}$ \\ 1) Research Institute for Marine Fisheries \\ 2) Faculty of Fisheries and Marine Science, Bogor Agricultural University, Bogor \\ 3) Research Institute for Freshwater Aquaculture \\ Received November 30-2009; Received in revised form April 29-2010; Accepted May 31-2010
}

\begin{abstract}
The genetic diversity study of bigeye tuna in Indonesia from Indian Ocean has never been done. One of the analysis to obtain information on the genetic diversity is by using the PCR-RFLP technique. The objectives of this study were to analyze the genetic diversity and genetic distance within population of bigeye tuna from Indian Ocean, south of Java and Nusa Tenggara based on mitochondrial DNA analysis with the PCR-RFL.P technique. The results show that the value of haplotype diversity (genetic diversity) from bigeye tuna population varied between $0.5578-0.8136$. The value of haplotype diversity was relatively high compare with marine fish species other fast swimmers such as sharks, indicated that the condition of bigeye tuna population was undisturbed. The average of genetic distance among the sample group was 0.2572 . Based on the genetic distance, bigeye tunas Indian Ocean, south of Java, and Nusa Tenggara were divided into two population groups (subpopulations), the first group was bigeye tuna from the sample groups 2, 5, and 1, and the second group was from the sample groups 3 and 4 .
\end{abstract}

KEYWORDS: genetic diversity, bigeye tuna, mitochondrial DNA, PCR-RFL.P

\section{INTRODUCTION}

Bigeye tuna (Thunnus obesus) is one of the Scombrid family members and is one of the most important tuna fishery export commodities of Indonesia's than yellowfin tuna (Thunnus albacares) and southern bluefin tuna (Thunnus maccoyii). Along with the increasing market demand from year to year, the higher the exploitation of bigeye tuna species, in the Indian Ocean, mainly in the fishing grounds of tuna longline vessels PT. Perikanan Samodra Besar Benoa Bali, has indicated over fishing. During this period over the last decade, the average weight of tuna caught, hook rate and the catch per unit effort tends to decrease (PT. Perikanan Samodra Besar 2006, in Kosasih, 2007). Therefore, it needs an appropriate management concept, in the long term to ensure a profitable catches (sustainable yield) but the sustainability of resources (spawning stock) is maintained. This concept will be implemented effectively if the available data on the condition of the bigeye tuna population with a clear definition and accurate.

One method that can be applied to determine the condition of the fish population and its genetic structure with a high degree of accuracy is based on DNA polymorphism, and mitochondrial DNA is believed to be relevant for the study. Other information that can be known are the diversity of genetic, molecular changes in the genome (mutations), and the phylogenetic relationships between populations.
Measurement method based on the genetic diversity of genotypes can be done by DNA analysis. DNA analysis can also be used to measure the kinship between species, population, taxonomic studies, and population genetics (Ryman \& Utter, 1987). DNA analysis has several advantages, among others are relatively unaffected by environmental factors and growth factors, more sensitive and more accurate results. DNA analysis can be done by several methods, one of which is the method of Restriction Fragment Length Polymorphism of Mitochondrial DNA.

Research on population genetics, particularly genetic diversity of fish in Indonesia have been implemented, such a is the mahseer fish population (Tor soro) originating from North Sumatra Province and West Java Province (Nugroho et al., 2006), red snapper (Lutjanus malabaricus) from some fishing grounds on the North Coast of Java and East Java Sea section (Suwarso, 2002) and yellowfin tuna from Bali region, North Maluku, and North Sulawesi (Permana et al., 2007).

The genetics diversity study of bigeye tuna in Indonesia from the Indian Ocean, has never been done. This is the underlying need for the research on the genetic diversity of bigeye tuna. The objectives of this study were to analyze genetic diversity and genetic distance within population of bigeye tuna from the Indian Ocean, south of Java, and Nusa Tenggara. 


\section{MATERIALS AND METHODS}

\section{Sampling Location}

Sampling activities of bigeye tuna were conducted in July until September 2008 located in the Indian Ocean, south of Java, and Nusa Tenggara. Bigeye tuna sampled was part of the catches of tuna longline vessels owned by PT. Perikanan Samodra Besar.

Three hundred specimens of bigeye tuna catches were taken from tuna longline vessels operating in the Indian Ocean south of Java and Nusa Tenggara. These specimens were divided into five groups of samples based on the sample vessels catching tuna longline PT. Perikanan Samodra Besar. The sampling location can geographically depicted at the coordinates $09^{\circ} 11^{\prime}-16^{\circ} 07^{\prime} S$ and $110^{\circ} 15^{\prime}-118^{\circ} 35^{\prime} \mathrm{E}$.

The specimens of bigeye tuna were taken its tail fin later was measured length and weight, and then recorded the location of fishing ground. The fins fish were cut off the ends, and then inserted into a sample bottle that had been washed and filled with a solution of absolute alcohol as a preservative. After that, sample bottles sealed and labeled. The collection of specimen samples and field data aided by field workers (observers) who have been appointed.

\section{DNA Extraction}

The DNA-fish was extracted as much as $5-10 \mathrm{mg}$. pieces of fish fins inserted into $1.5 \mathrm{~mL}$ microtube containing $500 \mu \mathrm{l}$ of urea solution. These materials were diluted in $200 \mathrm{~mL}$ aquades, then filtered. Then microtube added into $10 \mu \mathrm{l}$ of proteinase kinase (20 $\mathrm{mg} / \mathrm{mL}$ ), stirred with a vortex, and then stored in a waterbath incubator for 24 hours at $37^{\circ} \mathrm{C}$. After incubation was completed, $500 \mu$ of equilibrated phenol added into microtube, and then stirred again by using a vortex, and finally centrifugeg at 10,000 rpm for 10 minutes. Supernatant layer was formed on the top layer and taken using micropipet and transfered into a new microtube $10 \mu \mathrm{l} \mathrm{CH} \mathrm{H}_{3} \mathrm{COONa}$ and $1,000 \mu \mathrm{l}$ $90 \%$ ethanol was added. If the white threads were already visible, indicating that DNA had been formed Then sentrifuged at $10,000 \mathrm{rpm}$ for 10 minutes until it forms a white precipitate (pellets). After the pellets were formed, the liquid at the top of was discarded. Then the pellets were dried at room temperature and add $100 \mu \mathrm{l}$ of DNA rehydration solution. Then, the extracted stored at $4^{\circ} \mathrm{C}$ before use at a later stage.

\section{Amplification of mtDNA Region}

The primer used to sequence amplification of the D-loop mitochondrial were the primer Pro-5 (CAC GAC GTT GTA AAA CGA CCT ACC YCY AAC TCC CAA $A G C$ ), and the primer 12SAR (GGA TAA CAA TTT CAC ACA GGG CAT AGT GGG GTA TCT AAT CC). Amplification performed using the PCR method with a reaction composition comprising $3 \mu$ l of DNA, $2 \mu \mathrm{l}$ of each primer, $18 \mu \mathrm{l}$ of water free nuclease and pure taq DNA with a total volume of $25 \mu \mathrm{l}$.

PCR amplification cycle was applied in a single cycle of denaturation at a temperature of $95^{\circ} \mathrm{C}$ for 2 minutes, 35 cycles of reproduction $95^{\circ} \mathrm{C}$ during 1 minute, $45^{\circ} \mathrm{C}$ for 1 minute and $75^{\circ} \mathrm{C}$ for 2.5 minutes then, one last cycle at $72^{\circ} \mathrm{C}$ for 10 minutes, then stored in a temperature of $4^{\circ} \mathrm{C}$ for 5 minutes.

DNA resulted PCR taken as many as $3 \mu \mathrm{l}$ and added with $3 \mu$ of loading dye. After the test was performed and the results were visualized electrophoresisly under ultraviolet using a ultraviolet illuminator.

\section{MtDNA Restrictions and Visualization of Restriction Results}

MtDNA sequences obtained by using the endonuclease were restricted in accordance with the procedure $3 \mu \mathrm{LNA}+2 \mu \mathrm{l}$ buffer $+0.3 \mu \mathrm{l}$ restriction enzyme+14.7 $\mu$ l water free nuclease, after which centrifuge briefly and then incubated at $37^{\circ} \mathrm{C}$ for 24 hours. The results of restriction were then separated by electrophoresis using 2-3\% agarose gel in TrisBoric-EDTA buffer and observed by ultraviolet illuminator and photographed with a Polaroid picture.

\section{Data Analysis}

Haplotype composite data were analyzed to obtain genetic parameters, population structure, and phylogenetic relationships among populations the level of genetic diversity is measured by haplotype diversity index $(h)$ is calculated by using the data-frequency distribution based haplotype Nei \& Tajima (1981), kinship in the population parameters were determined based on Genetic Distance (Nei, 1972) and statistical analysis of restriction site differences. Genetic distances calculated according to Nei (1978), degrees of molecular differences in populations haplotype were guessed using a paired test Fst, phylogenetic 
relationships with in the population represented in the form of the clustering dendrogram of genetic distance values according to the method of the average range.

Calculation was done with the help of software package at tools for population genetics analysis (Miller, 1997).

\section{RESULTS AND DISCUSSION}

\section{Extraction and Amplification}

After amplification (PCR) D-Loop mtDNA, only 190 samples can be viewed restriction sites. The results of amplification of mtDNA D-Loop in bigeye tuna using primer Pro-5 and primer 12SAR generate a DNA fragment size of approximately $1,500 \mathrm{bp}$ in all samples bigeye tuna (Figure 1).

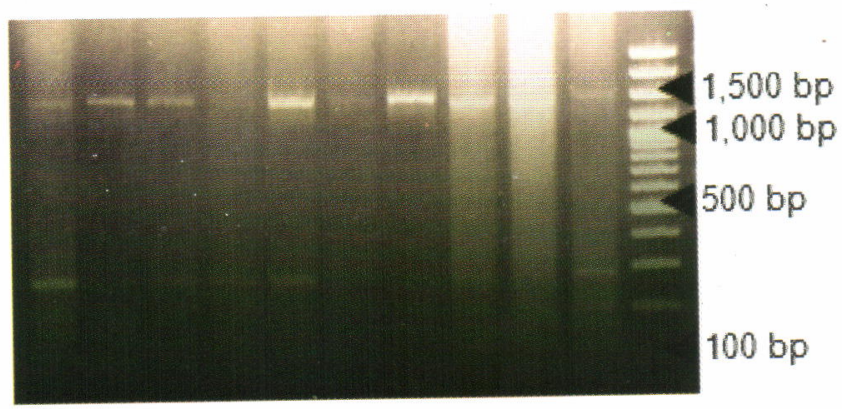

Figure 1.

Fragments of a single mtDNA PCR amplification of bigeye tuna.

In the primer there is only one visible DNA band on the gel agaros with an estimated size of 1,500 bp. This indicates that the primers used are specific primers for bigeye tuna.

\section{Cutting with Restriction Enzymes}

The results of the PCR product cut with four restriction enzymes produced 23 composite haplotypes mtDNA D-loop region. Type composite obtained haplotype presented in Table 1. Each restriction enzyme has a type (type of cut) different.

The diversity of the site and size of restriction fragments obtained from the mtDNA with four restriction enzymes were 18 types of restriction that Taq I and Hin6 I with four types of restriction A, B, C, and D (Figure 2a and 2b), Afa I and Mbo I with five types of restriction $A, B, C, D$, and $E$ (Figure $2 c$ and $2 d$ ). Based on the mtDNA restriction types, enzymes Afa I, and Mbo I with five types of restriction is the most sensitive enzymes to detect truncated fragment length differences than enzymes Taq I and Hin6 I.

Enzyme Taq I produce the restriction type $A$ monomorfic in the sample group 5 , three types of restrictions $(A, B$, and $C)$ in the sample group 1 and four restriction types $(A, B, C$, and $D)$ in the sample group 4. Type $A$ and $B$ found in the sample groups 2 and 3 , where the sample group 2 type $B$ is more dominant, whereas in the sample group 3 types $A$ and $\mathrm{B}$ are almost the same.

Enzyme Afa I produce two types of the same restriction on the sample groups 2 and 3 , and 3 types of restriction on the sample groups 1,4 , and 5 , but different restriction sites. The dominant type $B$ was found in all sample groups. Type $C$ is found only in the sample group 1 , type $D$ in the sample group 4 and type $\mathrm{E}$ in the sample group 5 .

Enzyme Mbo I produced 2-4 types of restrictions, where the dominant type $A$ in all sample groups. In the sample groups 2 and 5 found two types same restriction of type $A$ and $C$, the sample groups 1 and 4 found three types of restriction, but different restriction sites, and only the sample group 3 have four types of restriction.

Enzyme Hin6 I produces two types of the same restriction on the sample groups 1 and 2 , and three types of the same restriction on the sample groups of 3,4 , and 5 . Type B was found in all sample groups except the sample group 2 . 


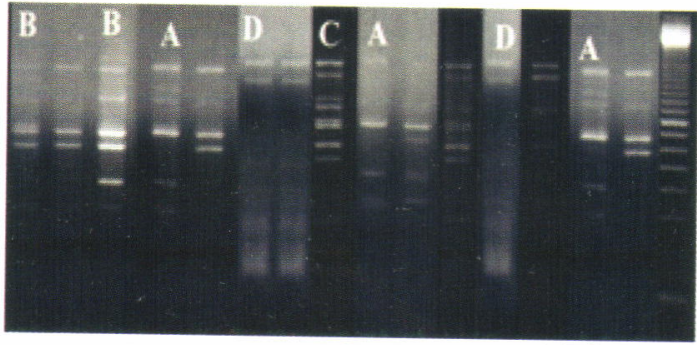

(a)

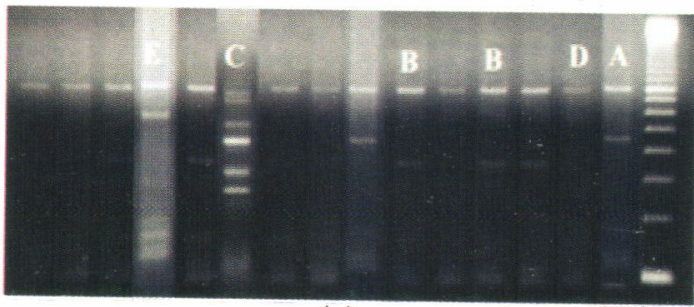

(c)

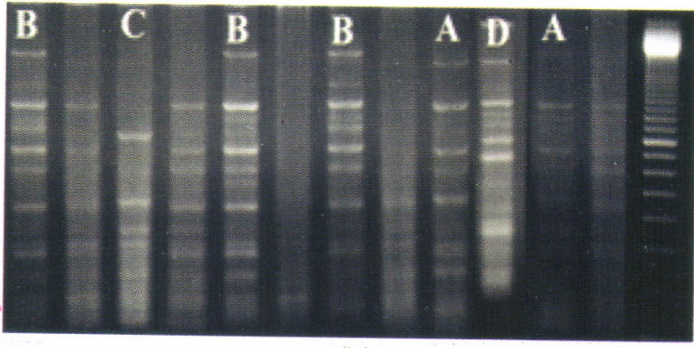

(b)

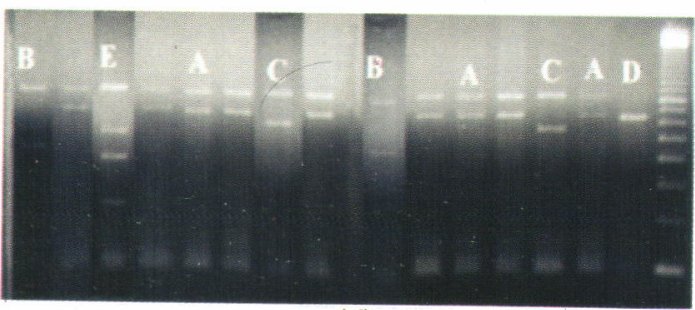

(d)

Figure 2 .

Type of restriction with enzymes Taq I (a), Hin6 I (b), Afa I (c), and Mbo I (d).

The results of cutting showed the different fragments length measure will provide different types of cuts. Different type of cutting on each individual in a population and between populations can be caused by the change, addition or loss of a particular base sequence of base pairs in the D-Loop mtDNA was so certain enzymes do not cut on the same site. This resulted in a shift in the cutting site. Thus it can be said that there are differences in the sequence of base pairs on the type of individuals that have a different base cuts. This indicates the existence of genetic diversity in the population.

\section{Haplotype Diversity}

Haplotype composite analysis produce 23 composite haplotypes in all sample groups (Table 1). The lowest amount of 7 composite haplotypes was observed in the sample group 5, whereas the highest amount of was found 12 composite haplotypes in the sample group 1. Haplotype diversity values varied between 0.5578-0.8136.

Haplotype composite BBAB distributed in all groups where the highest sample of $65 \%$ was found in the sample group 5, the next sequence of $54 \%$ was found in the sample group 2, 50\% the sample group $1,30 \%$ the sample group 4 , and lowest of $27 \%$ in the sample group 3.

Haplotype composite $A B A B$ distributed in four sample groups where the highest of $43 \%$ was found in the sample group 3, the next sequence of $24 \%$ was found in the sample group $4,14 \%$ the sample group 1, and lowest $5 \%$ in the sample group 2 . Haplotype composite BBAB and BBCB distributed in all sample groups, while $A B A B$ distributed in four sample groups i.e the sample groups 1, 2, 3, and 4 . Haplotype composite BBAB and BBCB provide the main haplotype (major composite haplotypes) as were found in five sample groups, whereas a haplotype $A B A B$ general (common haplotype) and there were found in four from five sample groups.

The fifth sample group was also characterized by a unique composite haplotype, the haplotype composite contained in one sample group but not in the other sample groups. Haplotype composite AAAA, BABA, CBAA, BCAA, ABAD, BADA, CBEB, BDAA, DBAA, DBAB, BAAC, and haplotype composite $B E A B$ was unique, each one only found in different sample groups. Haplotype composite AAAA, BABA, $C B A A$, and $B C A A$ are found only in the sample group $1, A B A D$ was found only in the sample group 2, BADA found only in the sample group 3, CBEB, BDAA, $D B A A, D B A B$, and BAAC were found only in the sample group 4 and $B E A B$ in the sample group 5.

Based on the type haplotype $\mathrm{BBAB}$ and $\mathrm{BBCB}$, that were found in all sample groups, showing geographical proximity. Thus genetically it is likely that five sample groups have the same original stock. 
Frequency distribution of the haplotype composite type in five sample groups of bigeye tuna

\begin{tabular}{|c|c|c|c|c|c|c|}
\hline \multirow[b]{2}{*}{$\begin{array}{c}\text { Haplotype } \\
\text { composite types }\end{array}$} & \multicolumn{6}{|c|}{ Haplotype frequency $(\%)$} \\
\hline & Total & $\begin{array}{l}\text { Sample } \\
\text { group } 1\end{array}$ & $\begin{array}{l}\text { Sample } \\
\text { group } 2\end{array}$ & $\begin{array}{l}\text { Sample } \\
\text { group } 3\end{array}$ & $\begin{array}{l}\text { Sample } \\
\text { group } 4\end{array}$ & $\begin{array}{l}\text { Sample } \\
\text { group } 5\end{array}$ \\
\hline AAAA & 1 & 0.02 & - & - & - & - \\
\hline $\mathrm{BBAB}$ & 86 & 0.50 & 0.54 & 0.27 & 0.30 & 0.65 \\
\hline $\mathrm{ABAB}$ & 33 & 0.14 & 0.05 & 0.43 & 0.24 & - \\
\hline $\mathrm{BAAB}$ & 4 & 0.04 & 0.03 & - & - & 0.03 \\
\hline BBAA & 14 & 0.14 & 0.08 & - & 0.03 & 0.10 \\
\hline $\mathrm{BABA}$ & 1 & 0.02 & - & - & - & - \\
\hline $\mathrm{BBCA}$ & 3 & 0.02 & - & - & 0.03 & 0.03 \\
\hline $\mathrm{BBCB}$ & 16 & 0.04 & 0.15 & 0.05 & 0.12 & 0.06 \\
\hline $\mathrm{ABCB}$ & 4 & 0.02 & - & 0.08 & - & - \\
\hline BBBA & 3 & 0.02 & - & 0.05 & - & - \\
\hline CBAA & 1 & 0.02 & - & - & - & - \\
\hline $\mathrm{BCAA}$ & 1 & 0.02 & - & - & - & - \\
\hline BAAA & 5 & - & 0.08 & 0.05 & - & - \\
\hline ABAA & 5 & - & 0.03 & - & 0.12 & - \\
\hline $\mathrm{BBAC}$ & 5 & - & 0.03 & 0.03 & - & 0.10 \\
\hline $\mathrm{ABAD}$ & 1 & - & 0.03 & - & - & - \\
\hline BADA & 1 & - & - & 0.03 & - & - \\
\hline CBEB & 1 & - & - & - & 0.03 & - \\
\hline BDAA & 1 & - & - & - & 0.03 & - \\
\hline DBAA & 1 & - & - & - & 0.03 & - \\
\hline DBAB & 1 & - & - & - & 0.03 & - \\
\hline BAAC & 1 & - & - & - & 0.03 & - \\
\hline BEAB & 1 & - & - & - & - & 0.03 \\
\hline Number of samples & 190 & 50 & 39 & 37 & 33 & 31 \\
\hline $\begin{array}{l}\text { Number of haplotype } \\
\text { composite types }\end{array}$ & & 12 & 9 & 8 & 11 & 7 \\
\hline Haplotype diversity & & 0.7048 & 0.6693 & 0.7232 & 0.8136 & 0.5578 \\
\hline
\end{tabular}

Haplotype diversity values obtained ranged from 0.5578 in the sample group 5-0.8136 in the sample group 4 (Table 1). Haplotype diversity value, in general was highly dependent on sample size (Nei, 1981; Tabata \& Mizuta, 1997 in Rina, 2001).

The level of genetic diversity, as indicated by the number and haplotype diversity of bigeye tuna were observed equivalent to the number of other marine fish haplotype numbering between 6-17 with the value of diversity $0.600-0.900$ (Nugroho, 2001). The results of genetic diversity of a bigeye tuna by Bremer et al. (1998) in the Atlantic Ocean, Indian Ocean, and Pacific Ocean showed that bigeye tuna from the three waters have 13 haplotype composites, where the Indian Ocean has 5 haplotype composites. Similarly, the haplotype composite yellowfin tuna the result of research by Permana et al. (2007) from the Bali waters, North Sulawesi, and North Maluku has 15 haplotype composites.

The average value of genetic diversity was 0.6937 . This value is lower than the value of the average diversity of yellowfin tuna, 0.857 (Permana et al., 2007), but higher compared with marine fish species other fast swimmers such as sharks (0.64) (Heist,
1999 in Permana et al., 2007). Graves \& McDowell (1994) in Tabata et al. (1997) explains that the diversity of the entire mtDNA haplotype striped marlin was 0.82 and Avise et al. (1989) in Tabata et al. (1997) states that the overall mtDNA haplotype diversity for some fish were in the range of 0.473-0.998. Relatively high genetic diversity in bigeye tuna provides an indication that the population has not substatially been affected, especially the group samples 4 and 3 . In addition, this situation also showed that bigeye tuna have possesing higher levels of migration behaviour than other marine water fish, so opportunity to cross with other populations was greater (Wild, 1994 in Permana et al., 2007).

Smallest haplotype diversity of 0.5578 of bigeye tuna in the sample group 5 and the highest of 0.8136 in the sample group 4 . This phenomenon indicates that the population of bigeye tuna from the sample group 5 have a low genetic diversity and has a smaller size than the four other sample groups. Leary et al. (1985) in Ayu (2005), states that the low genetic diversity would result in the emergence of negative characteristics, including decreased growth rate, variation of size, stability of organ development, survival rate and adaptation to environmental change. 


\section{Genetic Distance}

Based on Fst value comparison test between the sample groups using the program TFPGA noted that the difference between the sample group 1 with the sample groups 3 and 4 , the sample group 2 with the sample groups 3 and 4 , the sample group 3 with the sample groups 4 and 5 and the sample group 4 with the sample group 5 were exist. There is no significant difference between the sample group 1 with the sample groups 2 and 5 and the sample group 2 with the sample groups 5. The test results of diversity between the five group samples of bigeye tuna by the method of paired distances (Fst) is presented in Table 2.

Genetic distance between the group sample and the dendrogram of kinship between the sample group (phylogeny) in five groups of bigeye tuna by using the UPGMA method TFPGA program is presented in Table 3 and Figure 3 . The smaller the genetic distance values obtained, the closer the two groups are diverse and vice versa.

Table 2.

Diversity of five sample groups of bigeye tuna based on pairs distance methods (Fst)

\begin{tabular}{ccccccc}
\hline Sampel groups & 1 & 2 & 3 & 4 & 5 \\
\hline 1 & - & $0.1266^{5}=0.0174$ & $0.0000^{s}=0.0000$ & $0.0065^{s}=0.0024$ & $0.1479^{n}=0.0143$ \\
2 & - & $0.0000^{s}=0.0000$ & $0.0139^{s}=0.0045$ & $0.3043^{n}=0.0151$ \\
3 & & - & $0.0223^{s}=0.0065$ & $0.0000^{s}=0.0000$ \\
4 & & & - & $0.0000^{s}=0.0000$ \\
5 & & & & - \\
\hline
\end{tabular}

Table 3. Genetic distance between bigeye tuna

\begin{tabular}{cccccc}
\hline Sampel groups & 1 & 2 & 3 & 4 & 5 \\
\hline 1 & - & 0.0596 & 0.3545 & 0.1840 & 0.0589 \\
2 & & - & 0.5145 & 0.2178 & 0.0383 \\
3 & & & - & 0.1615 & 0.6621 \\
4 & & & & - & 0.3261 \\
5 & & & & & - \\
\hline
\end{tabular}

Bigeye tuna from the sample group 1 had a long genetic distance with the sample group 3, but has a close genetic distance with the sample groups 2 and 5. The group sample 2 had a long genetic distance with the sample group 3, but has a close genetic distance with the sample group 5. The group sample 3 had a long genetic distance with the sample group 5 , but has a close genetic distance with the sample group 4. Of all the sample groups, bigeye tuna from the sample groups 3 and 5 have a genetic distance of the farthest to the value 0.6621 , while the closest genetic distance of 0.0383 was between the sample groups 2 and 5.

Value of low genetic distance between sample groups 1 and 2, 1 and 5, and 2 and 5 show the closeness the sample groups. It is likely that the three sample groups are not limited geographically to one another. This situation causes the migration process and the exchange of genes between groups of samples occurs.

The average genetic distance between the sample group of bigeye tuna is around 0.2572. Dendrogram which was established by genetic distance showed that the observed sample group can be divided into two population groups (subpopulations), the first group consisted of bigeye tuna from the sample groups 2 , 5 , and 1, whereas the second group consists of the sample groups 3 and 4 (Figure 3 ).

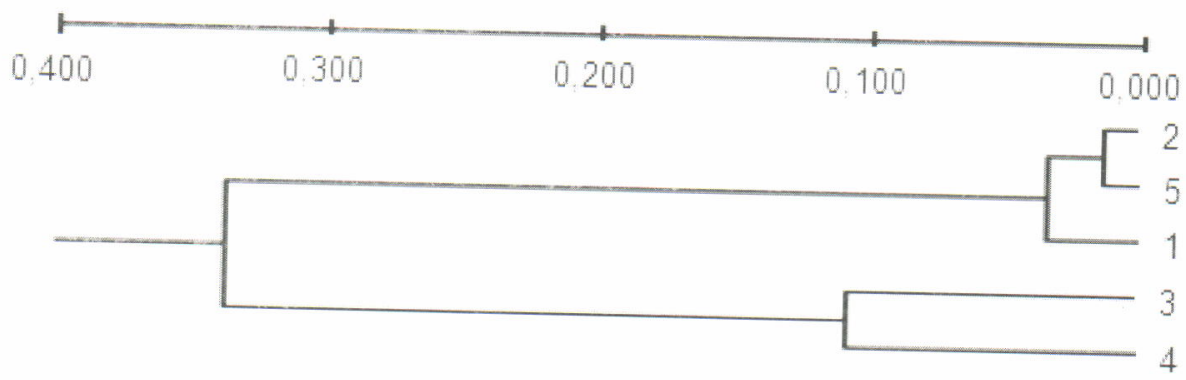

Figure 3.

Dendrogram of phylogenetic of five sample groups of bigeye tuna. 


\section{Tuna Fisheries Management Implications}

A population with high genetic diversity provide an indication that the population in nature is still not much disturbed. Conversely, if the genetic diversity of a population is low, the low natural population as well. Analysis of the five groups of samples bigeye tuna in the Indian Ocean indicate that the genetic diversity were relatively high, but the sample group 5 has a low genetic diversity. Based on these findings, fisheries management can be done should include short-term goals (related to the excess fishing capacity) and long term goal of conservation programs, so the sustainability of resources with optimal catches can be achieved.

Fishing activity is not evenly distributed among the fishing grounds, such as excessive fishing in certain areas, may result in loss of genetic diversity. Therefore, in the natural habitat such as in the sample group 5 a close fishing season should be introduced for a while or limit fishing effort due to low genetic diversity. In the natural habitat of the four other populations that still have good genetic diversity management must be directed toward to avoid overfishing by implementing production quotas and limited access on the number of fishing fleets.

\section{CONCLUSIONS}

1. Value of haplotype diversity (genetic diversity) of the sample group of bigeye tuna varied between $0.5578-0.8136$. This value is relatively high so that gives an indication that the state's of bigeye tuna population has not been much disturbed, especially in the sample groups 4 and 3 .

2. The average genetic distance between the population was 0.2572 . Similar genetic distance exists between the sample groups 2 and 5 . Based on genetic distance within populations, bigeye resources can be divided into two population groups (subpopulations), the first group consisted of bigeye tuna from the sample groups 2, 5, and 1, and the second group consisted of the sample groups 3 and 4 .

\section{SUGGESTION}

To avoid the decline in genetic diversity in bigeye tuna populations, which will lead to declining fish populations in the Indian Ocean, south of Java and Nusa Tenggara, the management measures are required. Management of fisheries in these waters is by implementing catch quotas and limitation on the amount fishing fleet.

\section{ACKNOWLEDGMENT}

This paper was part of the results of research on genetic population study using genetic marker DNA and reproductive biology of tuna in Indian Ocean and Funded by Research Center for Capture Fisheries, 2008.

\section{REFERENCES}

Ayu, H. S. 2005. Evaluation of genetic diversity of four population genetic diversity of four populations of tilapia fish (Oreochromis niloticus) based on analysis of mtDNA D-loop (in Indonesia). Thesis. Department of Fisheries. Faculty of Fisheries. University of Juanda. Bogor.

Bremer, J. R. A., B. Stequert, N. W. Robertson, \& B. Ely. 1998. Genetic evidence for inter oceanic subdivision of bigeye tuna (Thunnus obesus) populations. Marine Biology. 132: 547-557.

Kosasih. 2007. Development strategy tuna longline fishery Indonesia Tuna Longline Association (Case Studies in Benoa Bali) (in Indonesia). Thesis. Graduate Programs. Bogor Agricultural University. Bogor.

Miller, M. P. 1997. Tools for Population Genetic Analyses Version 1.3. Department of Biological Sciences-Box 5640. Northern Arizona University.

Nei, M. 1972. Genetic Distance Between Populations. American Nature. 106: 283-292.

Nei, M. 1978. Molecular Evolutionary Genetics. Columbia University Press. New York.

Nei, M. \& F. Tajima. 1981. DNA polymorphism detectable by restriction endonucleases. Genetics. 97: $145-163$

Nugroho, E. 2001. Capability of Mitocondria DNA-Loop Markers for Shark Species Identification. Indonesian Fisheries Research Journal. 7 (1): 62.

Nugroho, E., J. Subagja, S. Asih, \& T. Kurniasih. 2006. Evaluation of kancra fish genetic diversity using marker mtDNA D-loop polymorphism and Random Amplified DNA (in Indonesia). Aquaculture Research Journal. 1 (2): 211-217.

Permana, G. N., J. H. Hutapea, Haryanti, \& S. B. M. Sembiring. 2007. Genetic variations of yellowfin tuna, Thunnus albacares by allozyme 
electrophoresis analysis and Mt-DNA (in Indonesia). Aquaculture Research Journal. 2 (1): 41-50.

Ryman, N. \& F. Utter. 1987. Population Genetics and Fishery Management. Washington Sea Grant Program. London.

Rina. 2001. Genetic diversity of Indonesia pangasius fish based on mitochondrial DNA analysis by PCRRFLP technique (in Indonesia). Thesis. Graduate Program. Bogor Agricultural University. Bogor.
Suwarso. 2002. Geographic variation in population genetic structure of red snapper, Lutjanus malabaricus (Lutjanidae) and environmental interaction in the Java Sea (in Indonesia). Thesis. Graduate Program. Bogor Agricultural University. Bogor

Tabata K. H. Kishioka, M. Takagi, A. Mizuta \& N. Taniguchi. 1997. Genetic diversity of five strains of red seabream Pagrus major by RFLP analysis of the miDNA D-Loop region. Journal Fisheries Science. 63 (3): 344-348 